\title{
Yerli Elektrikli Aracın Elektrik Sarfiyatını Güneş ve Rüzgâr Enerjisi ile Karşılama Potansiyeli
}

\author{
Hüseyin Gürbüz ${ }^{1 *}$, \\ ${ }^{1 *}$ Şırnak üniversitesi, Makine Mühendisliği Bölümü, Şırnak, Türkiye (ORCID: 0000-0002-3561-7786), huseyinngurbuz@gmail.com
}

(İlk Geliş Tarihi 15 Mart 2021 ve Kabul Tarihi 30 Mayıs 2021)

(DOI: $10.31590 /$ ejosat.896937)

ATIF/REFERENCE: Gürbüz, H. (2021). Yerli Elektrikli Aracın Elektrik Sarfiyatını Güneş ve Rüzgâr Enerjisi ile Karşılama Potansiyeli. Avrupa Bilim ve Teknoloji Dergisi, (25), 58-69.

$\ddot{O} \mathbf{z}$

Son yılarda elektrikli araçların dünya genelinde artması paralelinde enerji ihtiyacı da artmıştır. Türkiye bu alana TOGG yerli elektrikli araç (EA) ile hızlı ve başarılı bir giriş yapmayı planlamaktadır. Fakat EA'lerin sayısının artması ile ülkemizin de enerji ihtiyacı artacaktır. Bu araştırmada yerli EA’lerin özelliklerine bağlı olarak araç sayılarına göre günlük ilave elektrik sarfiyatı hesaplanmıştır. Türkiyede dünyadaki gelişmelere bağlı olarak 20 yılın içinde 1 milyon adete ulaşması öngörülmektedir. Bu çalışmadaki yapılan araştırmada 1 , 100 bin ve 1 milyon aracın günlük elektrik sarfiyatı hesaplanmıştır. Bu ilave enerji tüketimini güneş enerji ve rüzgâr enerjisi ile karşılanabilme potansiyeli araştııılmıştır. Sonuç olarak ilave elektrik sarfiyatının tamamını potansiyel güneş enerjisi ile karşılamak için yaklaşık $1000 \mathrm{~kW}$ gücünde 5 milyon adet güneş paneline ve potansiyel rüzgâr enerjisi ile karşılamak için 2.159 MW gücünde yaklaşık 1390 adet rüzgâr türbinine ihtiyaç olduğu bulunmuştur.

Anahtar Kelimeler: Togg elektrikli araç, Enerji tüketimi, Güneş enerjsi, Rüzgâr enrjisi.

\section{The Potential of Providing of Electricity Consumption of The Domestic Electric Vehicle with Solar and Wind Energy}

\begin{abstract}
In recent years, the increase in the need for energy has increased in parallel with the increase of electric vehicles worldwide. Turkey has made a fast and successful entry into this field with the TOGG domestic electric vehicle (EA). However, with the increase in the number of EVs, the need for energy in our country will increase. In this research, daily additional electricity consumption was calculated according to the number of vehicles, depending on the characteristics of the TOGG Evs. In Turkey, depending on the developments in the world, it is seen that it will reach 1 million pieces within 20 years. In the research, daily electricity consumption of 1 vehicle, 100 thousand and 1 million vehicles was calculated. The potential for meeting this additional energy consumption with solar energy and wind energy was investigated. As a result, it was found that 5 million solar panels with approximately $1000 \mathrm{~kW}$ power were needed to meet all of the additional electricity consumption with potential solar energy and approximately 1390 wind turbines with 2,159 MW power were needed to meet with potential wind energy.
\end{abstract}

Keywords: Togg electric vehicle, Energy consumption, Solar energy, Wind power

\footnotetext{
* Sorumlu Yazar: huseyingurbuz@sirnak.edu.tr
} 


\section{Giriş}

İnsan ve çevre sağlığı açısından emisyonların olumsuz etkileri oldukça fazladır. Nox, $\mathrm{CO}$ ve $\mathrm{HC}$ gibi emisyonların özellikle insan sağlığı üzerinde doğrudan ve dolaylı olarak önemli zararları vardır (Ozsezen \& Canakci, 2011). Ulaşımda ve sanayide fosil yakıtların kullanılması, $\mathrm{CO}_{2}, \mathrm{CH}_{4}, \mathrm{~N}_{2} \mathrm{O}, \mathrm{O}_{3}$, Nox gibi sera gazları (GHG) emisyonları için iklim 1sınmasına neden olan önemli bir antropojenik kaynaktır (Allen et al., 2018; Behrentz et al., 2004). Ayrica dünya genelinde 2018 yilında salınan $\mathrm{CO}_{2}$ emisyonun \%24'ü ulaşım sektöründen kaynaklanmaktadır (Teter et al., 2020). Ayrıca dünya çapındaki enerji üretiminin yaklaşık\% 75 'inin fosil yakıtlardan sağlandığ 1 tahmin edilmektedir (Eriksson \& Gray, 2017; Manoharan et al., 2019). Son y1llarda fosil yakıtlara alternatif enerji kaynakları olarak kaya gazı kullanımı artmıştır (Cellek, 2020). Ulaşım sektöründe fosil yakıt kaynaklı zararlı emisyonların etkileri azaltmak için yeni standartlar getirilmektedir. Özellikle binek araçlarda emisyon standartları giderek sıkılaşmaktadır. Euro 6 düzenlemesinde partikül madde (PM) emisyonlarını artırmadan Nox emisyonlarında 0.180 $\mathrm{g} / \mathrm{km}$ 'den $\quad 0.080 \mathrm{~g} / \mathrm{km}$ 'ye (\%55) azalma öngörülmektedir (Williams \& Minjares, 2016). Özellikle dizel yanma, yüksek sıcaklıklar yarattığı için sera gazı etkili olan Nox emisyonuna neden olur (Pedrozo et al., 2016). Fakat Avrupa Birliği tarafindan yayınlanan raporda 2050 yılına kadar sera gazı emisyonlarını $\% 60$ azaltmayı hedeflemesine rağmen, 2010 hedeflerinin gerisinde kalmıştır (EEA, 2019). İçten yanmalı motorlarda kirletici emisyonları azaltmak için konvansiyonel yakıtlara ek olarak hidrojen, etanol, metanol, sıvılaştırılmış doğal gaz (LNG), sıkıştırılmış doğal gaz (CNG) ve sıvılaştırılmış petrol gazı (LPG) ve biyoyakıtlar gibi alternatif yakıtlar kullanılabilmektedir (Bae \& Kim, 2017; Gürbüz \& Sandalc1, 2019; Martins \& Brito, 2020). Ayrıca emisyonların oluşumunu engellemek veya azaltmak için yakıt enjeksiyon stratejileri, EGR, silindir içine su püskürtme, katalitik konvertör, sıkıştırma oranını değiştirme ve yakıt enjeksiyon basıncını değiştirme gibi birçok alternatif metot uygulanabilmektedir (Brijesh \& Sreedhara, 2013; Keskin \& Emiroğlu, 2016). Fakat artan taşıt sayısına bağlı olarak kirletici emisyonların oranı da artmaktadır. Hibrit ve elektrikli araçlar emisyonlarla mücadele çok önemli ivme kazandırmıştır (Z. Sun et al., 2020). Yakıt hücreli elektrikli araçlar (FCEV) ve bataryalı elektrikli araçlar (BEV) içten yanmalı motorlara ideal alternatif çözümlerdir (Gürbüz, 2020). Yakıt hücreli elektrikli araçlar (FCEV'ler), geleneksel içten yanmalı araçlara kıyasla emisyonları \%99.2 oranında azaltabilir (Z. Sun et al., 2020). Dünya genelinde emisyon standartlarının sıkılaşması ve bataryalardaki yeni olumlu gelişmeler nedeniyle elektrikli araçlara (EA) yönelik trend son dönemde önemli bir ivme ile artmaya başladı. Hibrit elektrikli araçlar (HEV'ler) ve bataryalı elektrikli araçlar (BEV'ler) yaygın EA türleridir. Ayrıca bataryalı elektrikli araçlarda piller şarj edilebilirler (López et al., 2019; Martínez-Lao et al., 2017). Fakat şekil 1 de görülen hibrit araçlarda ek güç kaynağı ve menzil uzatmak amacıyla içten yanmalı motorlar kullanıldığı için yakıt tüketimi ve kirletici emisyonları azaltsa da sıfırlanmamıştır (Huang et al., 2019; Rezaei et al., 2017; C. Sun et al., 2017). Tamamen elektrikli araçlarda ise konvansiyonel yakıt kullanımı olmadığı için HC, $\mathrm{CO}$, Nox ve partikül madde gibi ana kirletici emisyonlar söz konusu değildir. Elektrikli araçların (EA) (Kısaltma daha önce kullanılmış) genel yapısı şekil 2'de görüldüğü gibi elektrik motoru ve batarya olmak üzere iki ana elamandan oluşmaktadır (BMW, 2021). Ayrica EA enerji gereksinimini bataryalarda depolanan elektrik enerjisinden sağlar (Civles \& İrem, 2018; Sayın \& Yüksel, 2011). Fakat Elektrikli araçlarda en büyük sorun bataryaların kapasitesi ve verimliliğidir (Ghosh, 2020). Bataryaların kapasitesi ve elektrik motorun gücüne bağlı olarak EA menzili belirlenir (Mruzek et al., 2016; Traub, 2011). Piyasada bulunan EA'ın menzili ortalama $350 \mathrm{~km}$ 'dir. EA'ın tarihi oldukça eski olmasına rağmen bataryaların kapasite sorunu, maliyet yüksekliği ve şarj istasyonu alt yapı eksiliği ve menzil sorunları nedeniyle geri plana atılmasına rağmen son yıllarda konvansiyonel araçlar için uygulanan emisyon standartları giderek sıkılaşması bu araçları yeniden ön plana çıkarmıştır. Dolayısıyla bazı araç üreticileri elektrikli araç üretimine yönelmiştir. Bu firmalara Türkiye'nin otomobili alt başlı̆̆ı ile TOGG firması da güçlü bir ivmeyle katılım sağlamıştır (TOGG, 2020).

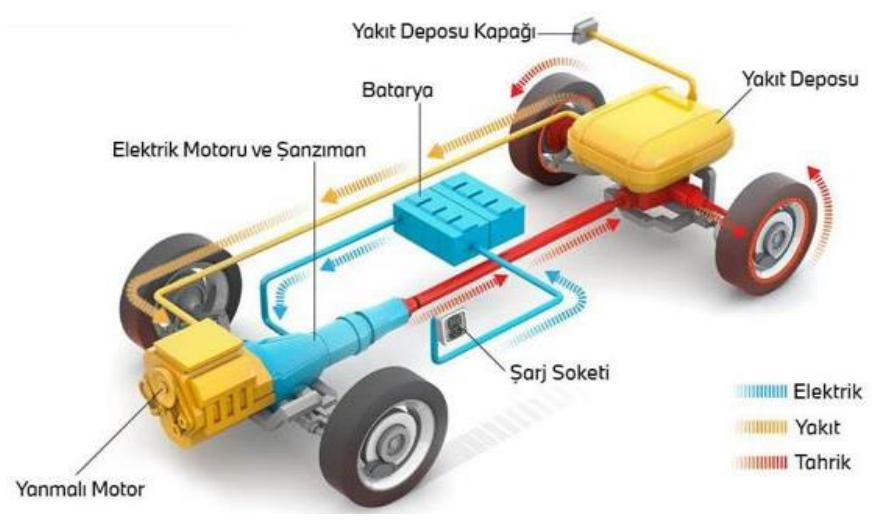

Şekil 1 Hibrit elektrikli aracın ana bileşenleri

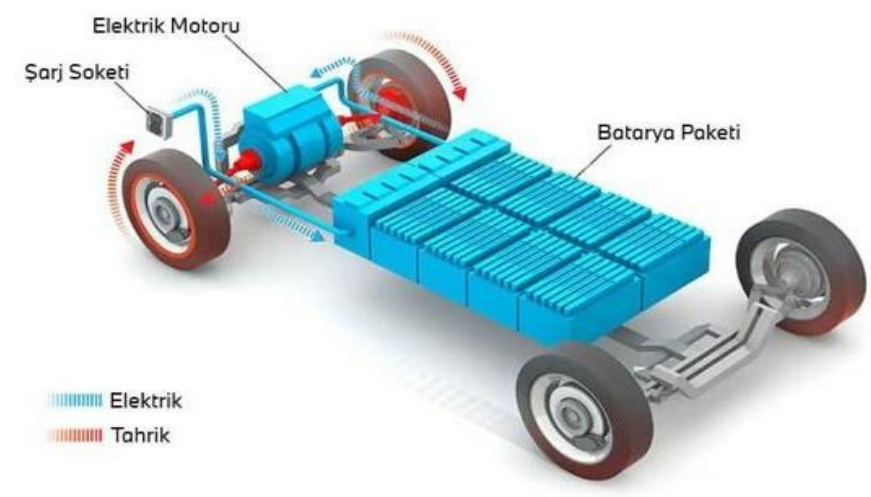

Şekil 2 Tamamen elektrikli aracın ana bileşenleri 


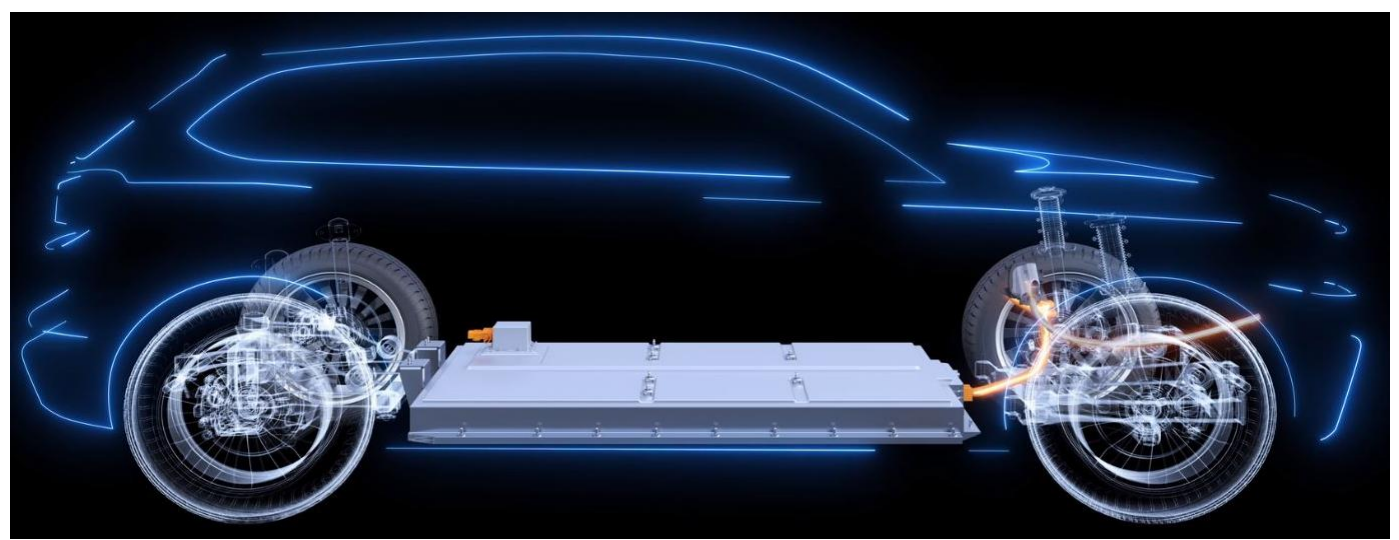

Şekil 3 TOGG elektrikli araç batarya yerleşimi

TOGG kendi ürettiği prototipi üretilen araç üzerinde konumu Şekil 3 'te gösterilen yüksek enerjili Lityum-iyon teknolojili 45 kWh ve $90 \mathrm{kWh}$ bataryalar ile araç menzilini 500+ km'ye kadar uzatmıştır. Ayrıca TOGG EA'cın Tablo 1 de gösterildiği gibi 150 $\mathrm{kW}$ ve $300 \mathrm{~kW}$ gücünde elektrik motoruna sahiptir (TOGG, 2020). Ayrıca birçok yeni donanımla aracı ile kendi sınıfında üst seviyelere çıkacağı gözükmektedir. Dünya pazarında elektrikli araç sayısı şekil 4 görüldüğü gibi 2018 yılında $\% 2$ artış ile 1 milyon araca, 2019 yılında 4.79 milyona ve 2020 yılında ise 7 milyona ulaşmıştır (Agency EA, 2019; Deloitte, 2019; IEA, 2019).

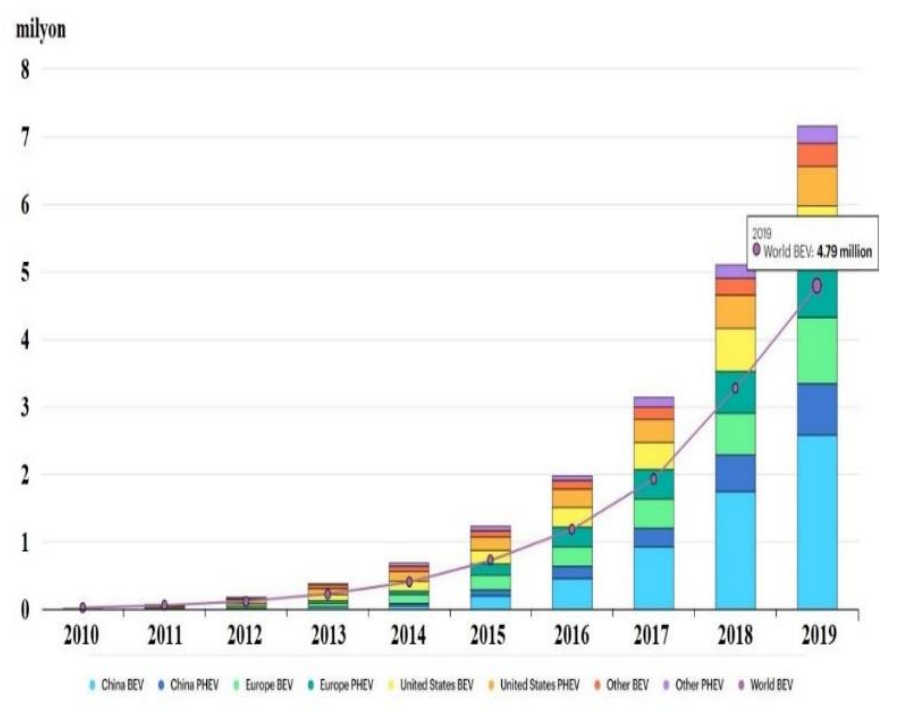

Şekil 4 EA'ların 2010-2019 yılları arasında ki sayısı

Elektrikli araç sayısı 2025 yılına kadar dünya genelinde 12 milyonu geçeceği öngörülmektedir (Adler, 2021). Ayrıca yapılan bazı modellemelere göre dünya geneli elektrikli araç sayısı 2030 yılında 120 milyon âdeti bulabileceği hesaplanmıştır (Çobanoğlu et al., 2021). Türkiye'de bulunan trafiğe kayıtlı elektrikli araç sayısı 2018 yılında yaklaşık \%27 artış ile 833 âdete, 2020 yılı itibari ile 1012 âdete ulaşmıştır (Saygın et al., 2019). Türkiye'deki EA sayısı 2025 yılında 100 bin, 2027 yılında 220 bin ve 2030 y1lında 550 bin âdete ulaşacağı öngörülmektedir (Saygın et al., 2019). Bu sayı gerek yerli elektrikli araç için yapılacak teşvikler ile gerekse de dizel araç gibi içten yanmalı motorlu araçlara getirilen sınırlamalar ile yurt içinde hızla artması öngörülmektedir (Saygın et al., 2019). Türkiye'de 2021 yılı itibari ile kayıtlı 13 milyon binek ve 5 milyon dizel binek araç e-ISSN: 2148-2683 bulunmaktadır (TUIKK, 2020). Türkiye'de yerli marka ve diğer firmalar ile EA 10 yıl içinde 2 milyon araç konvansiyonel araçlar ile yer değiştirmesi öngörülmektedir. Fakat EA'ların sayısındaki bu artış ülkenin toplam elektrik tüketimini olumsuz yönde etkileyecektir.

Dünyada oldu gibi Türkiye'de elektrikli araçlara önemli bir yönelim olması ve TOGG yerli elektrikli aracın kısa vade de üretime geçecek olması, acil şarj istasyonu alt yapı çalışmalarına ihtiyaç duymaktadır. Yerli elektrikli araç çalışmasının desteklenmesi için şarj istasyonlarının sayısının fazla olmasına ihtiyaç vardır. Fakat EA'lerin sayısının artması ile zamanla önemli oranda elektrik sarfiyatına ek yükü getirecektir. Bu ek yükün yenilebilir enerji kaynaklarından elde edilmesi dışa bağımlılığın azalması anlamına geleceğinden güneş enerji sistemleri (GES) ve rüzgâr enerji sistemleri (RES) kullanarak önemli oranda temiz enerji elde edilebilir. Bu çalışmada yerli elektrikli aracın teknik özellikleri kullanılarak 1 adet, 100 bin adet ve 1 milyon adet elektrikli aracın ülkemiz elektrik sarfiyatına ilave yükü ve bu ilave enerji ihtiyacı GES ve RES sistemleri ile temin edilebilirliği araştırılmıştır.

\section{Materyal ve Metot}

\subsection{Elektrikli Araçlarda Enerji Tüketimi}

Elektrikli araçlarda enerji tüketimi hesabına araca etki eden ivme direnci, hava direnci, eğim direnci ve yuvarlanma direnci kuvvetleri de hesaba katılmalıdır. Enerji tüketimi araç karakteristiği, yol ve hava koşulları ayrıca sürüş karakteristiğine göre değişir (De Cauwer et al., 2015; Wang et al.2015). EA'ların bir saniyedeki enerji tüketimi (Es) Ws cinsinden denklem 1 ile hesaplanır (Hyodo et al., 2013).

$\mathrm{Es}=M \cdot v \cdot \alpha+\frac{1}{2} \rho \cdot C_{D} \cdot A \cdot v^{3}+M \cdot \mathrm{g} \cdot \Delta_{h}+\tau \cdot M \cdot \mathrm{g} \cdot v$

M: kütle $(\mathrm{kg}), \quad v$ : hız $(\mathrm{m} / \mathrm{s}), \alpha$ : ivme $\left(\mathrm{m} / \mathrm{s}^{2}\right), \rho$ : hava yoğunluğu, $1.24\left(\mathrm{~kg} / \mathrm{m}^{3}\right), \mathrm{C}_{\mathrm{D}}$ : hava direnç katsayısı, $A$ : aracın ön cephe alanı $\left(\mathrm{m}^{2}\right)$, g: yer çekim ivmesi $\left(\mathrm{m} / \mathrm{s}^{2}\right), \Delta_{h}: 1$ saniyedeki yüksekli farkı $(\mathrm{m}), \tau$. yuvarlanma direnç katsayısını temsil etmektedir.

Elektrikli araçların enerji tüketimini menzil hesaba katılmadan düşünüldüğünde doğrudan aracın motor gücüne bağlı olarak denklem 2 ile hesap edilebilir. 
$E_{T}=G_{M} x \eta_{M} x X x t$

$E_{T}$ : araç enerji tüketimi $(\mathrm{kWh}), G_{M}:$ motor gücü $(\mathrm{kW}), \eta_{M}:$ motor verimi (\%), X: yük oranı, $t$ : süre $(\mathrm{h})$

Ayrıca elektrikli araçların enerji tüketimini doğrudan araç batarya kapasitesine ve şarj olma sayısına bağlı olarak denklem 3 ile hesap edilebilir.

$E_{V}=B_{G} x \eta_{B} x C_{n}$

$E_{V}$ : araç enerji tüketimi $(\mathrm{kWh}), B_{G}$ : Batarya gücü $(\mathrm{kWh}), \eta_{B}$ : batarya kapasitesi (\%), $C_{n}$ : şarj olma sayısı

Türkiye'de kısa vadede özellikle yerli elektrikli araçlar ile artacak olan elektrik tüketimini karşılayacak elektrik enerjisi üretilmelidir. Türkiye'nin kurulu elektrik üretim kapasitesi 2019 yılı sonunda 91.342 MWh 2020 yilın sonunda ise 96,271 MWh mertebesindedir (Hakyemez, 2021). Ayrıca elektrik üretim potansiyeli ve üretim kaynak çeşitliliği oldukça fazladır. Yenilebilir enerji kaynakları arasında rüzgâr enerjisi, güneş enerjisi, jeotermal enerji, biyokütle enerjisi ve dalga enerjisi başlıcalarıdır. Türkiye 2020 yılı verilerine göre kurulu gücün \%8.5 akarsu hidroelektrik, \%9.01 rüzgâr, \%22.4 yerli ve ithal kömür, \%27 doğal gaz, \%1.6 jeotermal, \%23.8 baraj hidroelektrik, \%1.5 biyokütle atık 1sı ve \% 7.01 güneş enerjisi kullanılarak elde edilmiştir (TEİAŞ, 2021).

\subsection{Güneş Enerjisi Potansiyeli}

Türkiye'nin güneş enerjisinden elektrik üretim potansiyeli oldukça iyidir. Türkiye'nin coğrafi konumu bu potansiyelde önemli etkendir. Yenilenebilir enerji kaynaklarından elde edilen enerjide güneş enerjinsin etkisi giderek artmaktadır. Güneş enerjisinden elektrik üretimi ile sıfir emisyon üretimi yapılır. Çevreye ve insan sağlığına doğrudan zararı yoktur. Ayrıca geniş arazi yelpazesine sahip olarak üretilebilir (Sarıkaya, 2012). Fakat güneş enerjisi iklim şartlarından etkilenir ve enerji üretimi gün içinde sürekli olmadığı gibi aynı zamanda anlık olarak istenilen yoğunlukta da olmayabilir (Sarıkaya, 2012). Ülkemizde güneş enerjisinden elektrik üretimi çok geç başlanmıştır. Dolaysıyla Türkiye toplam elektrik kurulu gücünün güneş enerjisi santrallerinin toplam kurulu güçteki payları $\% 7.1$ oran ile 6.805 MW seviyesindedir (Bayrak, 2020). Güneş enerjisi elektrik üretimindeki bu iyileşme 2008 da ki 2023 hedeflerinin oldukça üzerindedir (Sarıkaya, 2012). Bu oran 2021 yılında \%100 artış ile 13.610 MW seviyesine ulaşacağı öngörülmektedir. Ancak bu oran toplam kurulu gücün sadece \%13,1'ni karşılayacaktır. (Bayrak, 2020).

Güneş enerjisi sıcak su sağlanması, seraların 1sıtılması, binaları 1sıtılması, tarım ürünlerin kurutulması ve elektrik enerjisi üretimi gibi oldukça çeşitli kullanım alanı vardır (Doğanay, Özdemir, \& Şahin, 2020; Oral, 2020). Güneş Enerjisi Potansiyeli Atlası'na (GEPA) göre, Türkiye'nin güneşlenme süresi günlük olarak ortalama 7,5 saat olarak ve yıllık toplam güneşlenme süresi ortalama 2741,07 saat/yıl olarak belirlenmiştir (ETKB, 2020; Hacıbebekoğlu et al., 2013). Türkiye'nin güneş enerjisi potansiyel atlası haritası şekil 5'de gösterilmiştir (Enerji Atlası, 2021). Işınım alma sürelerine bağlı olarak güneş enerjisi üretim potansiyeli en düşük bölgeler Karadeniz, Marmara ve Trakya bölgeleri ve güneş enerjisi üretim potansiyeli en büyük bölgeler ise Güney Doğu Anadolu, Doğu Anadolu, İç Anadolu ve Akdeniz bölgeleridir. İl bazında ise güneş enerji yoğunluğu bakımından Van, Konya, Karaman, Mersin ve Antalya illerinde görülür. Türkiye coğrafi bölgelerinin 1şınım değerleri ve güneşlenme süreleri tablo 2'de gösterilmiştir (Özgür, 2020).

Tablo 2 Bölgelerin ışınım değerleri ve güneşlenme süreleri

\begin{tabular}{|l|c|c|}
\hline Bölge & $\begin{array}{l}\text { Güneşlenme Süresi, } \\
\text { (Saat/yıl) }\end{array}$ & $\begin{array}{l}\text { Toplam Güneş Enerjisi, } \\
\text { (kWh/m²-yll) }\end{array}$ \\
\hline Marmara & 2409 & 1168 \\
\hline Karadeniz & 1971 & 1120 \\
\hline Ege & 2738 & 1304 \\
\hline İç Anadolu & 2628 & 1314 \\
\hline Doğu Anadolu & 2664 & 1365 \\
\hline Güney Doğu Anadolu & 2993 & 1460 \\
\hline Akdeniz & 2956 & 1390 \\
\hline
\end{tabular}




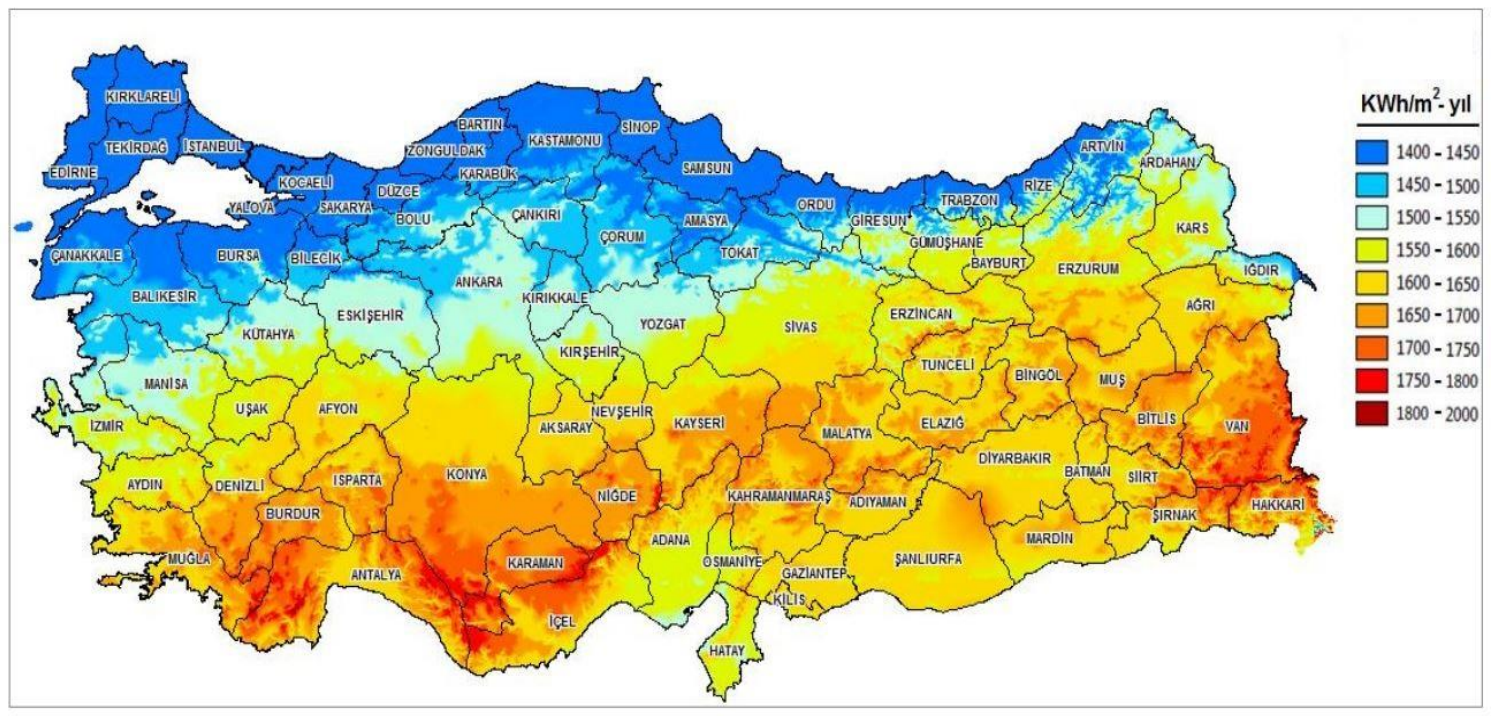

Şekil 5 Türkiye'nin güneş enerjisi potansiyel atlası haritası

Günümüzde güneş enerjisinden elektrik enerjisi üretiminde genelde Fotovoltaik (PV) ve Isıl Güneş Teknolojileri ve Odaklanmış Güneş Enerjisi (CSP) olmak üzere iki farklı teknoloji kullanılmaktadır (Özdoğan \& Bitlisli, 2019). Şekil 6'da gösterilen Fotovoltaik (PV) güneş enerjisi sistemleri yani güneş hücreleri, yarı iletken malzemelerden üretilir ve güneş 1şığını doğrudan elektrik enerjisine çevirirler. Odaklanmış Güneş Enerjisi ve 1sıl Güneş Teknolojileri güneş enerjisinden 1sı elde edilen bu sistemlerde, 1sı doğrudan kullanılabilir ayrıca elektrik üretiminde de kullanılabilir. PV sistemler her alana kurulabilmesi ve enerji nakil hatlarının olmadığı ve enerji üretimi için kurulum haricinde bir çalışmaya gerek olmamasından dolayı oldukça yaygın şekilde tercih edilmektedir. Ayrıca şekil 7'de görüldüğü gibi dünya genelinde otopark alanları üzerleri güneş panelleri ile kaplanarak şarj istasyonu uygulamaları mevcuttur.

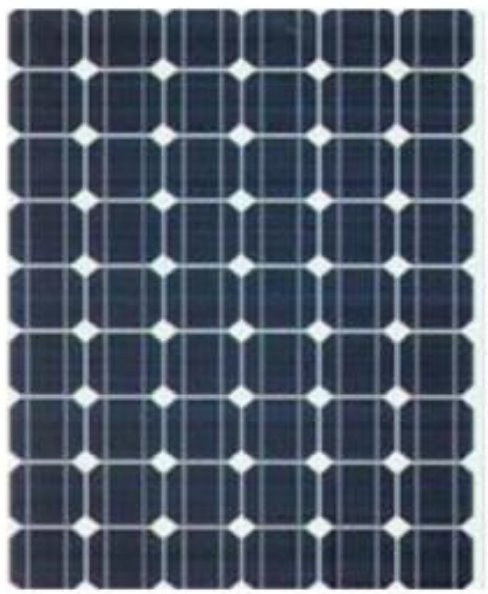

Şekil 6 Fotovoltaik panel görüntüsü

PV sisteminde güneş enerjinsin yetersiz olduğu anlarda veya gece enerji üretimi olmadığından dolayı eğer şebeke yoksa enerji depolamak için bir akümülatör ve DC 220 volt kullanımları için bir invertör bulunur. Güneş panelleri tablo 3 'de gösterildiği gibi 12-48 volt ve 153-1088 Watt güç aralığında paneller mevcuttur (GEP, 2021; Köroğlu et al., 2010).

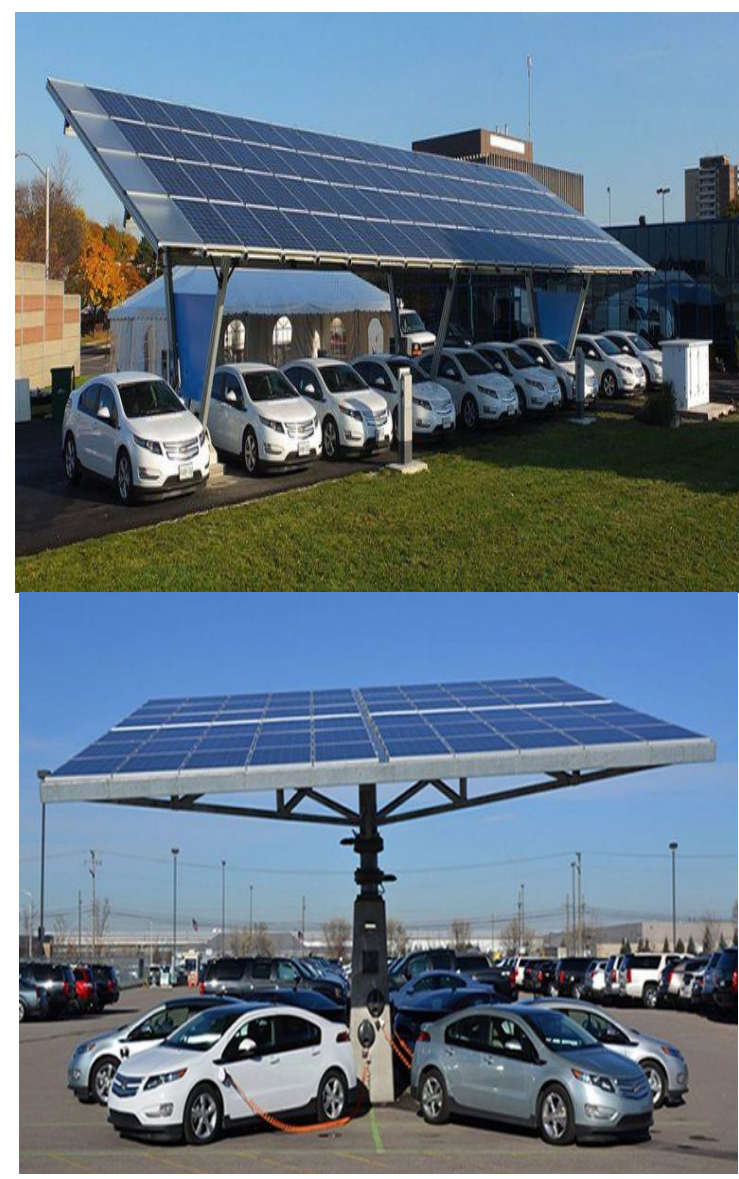

Şekil 7 Otopark güneş panelleri ile elektrik şarj istasyonları

Güneş panelleri elde edilecek gerilimi artırmak için seri, akımı artırmak için paralel bağlanarak modül oluşturulabilir (Atakul et al., 2015). 
Tablo 3 Güneş paneli güç ve voltaj değerleri

\begin{tabular}{|c|c|c|}
\hline $\begin{array}{c}\text { Nominal } \\
\text { Gerilim }\end{array}$ & $\begin{array}{c}\text { Panel Gücü, } \\
\text { Watt }\end{array}$ & $\begin{array}{c}\text { Maksimum Akım, } \\
\text { Amper }\end{array}$ \\
\hline \multirow{4}{*}{$12 \mathrm{v}$} & 153 & 9 \\
\cline { 2 - 3 } & 374 & 22 \\
\cline { 2 - 3 } & 544 & 32 \\
\cline { 2 - 3 } & 748 & 44 \\
\cline { 2 - 3 } & 1020 & 60 \\
\hline \multirow{3}{*}{$24 \mathrm{v}$} & 216 & 9 \\
\hline \multirow{3}{*}{$48 \mathrm{v}$} & 748 & 22 \\
\cline { 2 - 3 } & 340 & 5 \\
\hline
\end{tabular}

\subsection{Güneş enerjisinden elektrik üretim hesabı}

Son yıllarda artan elektrikli araç sayısı ile elektrik tüketimi artmış ve ani yük dalgalanmalarını güneş panelleri ile elektrik üretimi şebeke yükü azaltılabilir (Çiçek \& Erdinç, 2019). Dolayısıyla güneş enerjisinde elektrik üretmek için güneş panelleri elektrik üretimi araştırıldı. Güneş panellerinin konumu ve boyutuna bağlı olarak üretim potansiyeli değişmektedir. Ayrıca hareketli güneş paneli sistemleri de kullanılmaktadır. (Alkan et al. 2014). Yüksek verimli güneş panelleri kullanılabilir. $\mathrm{Bu}$ hesaplamada panellerin konumu ideal konum ve güneş alma süreleri Türkiye ortalaması olarak alınmıştır.

Panellerden üretilen elektrik kullanım açısından kayıplara uğrar. Güneş panelin verimi, akü verimi ve invertör verimi dikkate katılarak güneş paneli sistemi verim hesabı denklem 4'e göre hesaplanır (Alkan et al., 2014).

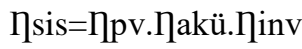

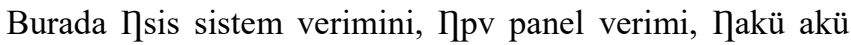
verimini, Пinv invertör verimini temsi etmektedir. Güneş panelinden çekilecek enerji denklem 5 ile hesaplanır.

YE=ÜGE.П] sis

Burada YE yükün enerjisini ve ÜGE üretilmesi istenen enerjiyi temsil etmektedir. Bu enerjiyi üretebilmek için kaç adet panele ihtiyaç olduğunu hesaplamak için denklem 6 kullanılır.

\section{$\mathrm{Ps}=E \dot{\mathrm{I}} / P G x G S$}

6

Burada Ps, panel sayısını, Eİ ihtiyaç olan enerjiyi, PG kullanılan panelin gücünü, GS güneşlenme süresini temsil etmektedir.

\subsection{Rüzgâr enerjisinden elektrik üretim hesabı}

Yenilenebilir enerji kaynaklarından en önemlilerinden biri rüzgâr enerjisidir. Türkiye'nin rüzgâr enerjisinden elektrik üretim potansiyeli oldukça fazladır. Türkiye'nin yüksek dağları bu potansiyelde önemli etkendir. Ayrıca rüzgârdan yararlanarak enerji üretimi ile sıfır emisyon salımı meydana gelir. Atmosfere zararlı karbondioksit ve nitrojen gazları salınımı yoktur. Rüzgâr enerjisi birçok iklim şartlarında ve rüzgâr hızında aktif olarak üretilebilir. Rüzgâr enerjisinde elektrik üretmek için genelde yatay eksenli rüzgâr türbinleri kullanılmaktadır. Türbin kanatlarının kinetik enerjisinin hareket enerjisine ve mekanik enerji dişli kutusu vasıtasıyla jeneratöre ileterek elektrik üretir. Rüzgâr türbinin genel yapısı şekil 8'de gösterilmiştir (Gezegen, 2021; Luo, 2010).

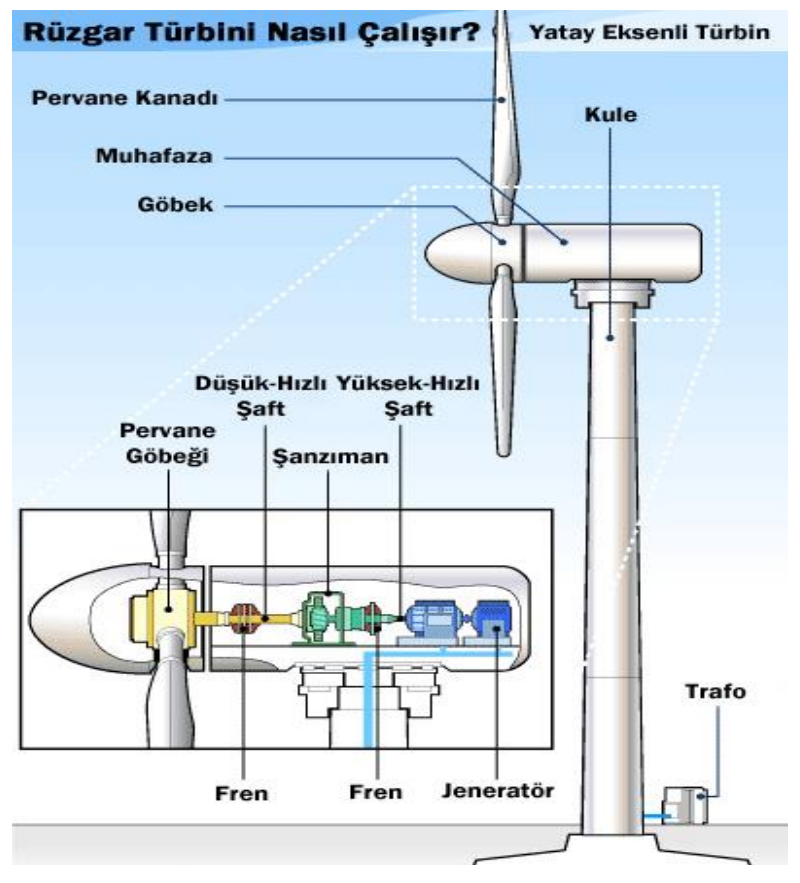

Şekil 8 Yatay eksenli rüzgâr türbini genel yapısı

Rüzgâr türbinleri sera gazı olmadan elektrik üretimi yaptığı için dünya genelinde hızla yayılmaya devam ediyor. Fakat rüzgâr türbinleri gürültü oluşturma, rüzgâr yavaş ve çok hızlı eserse durması ve yatırım maliyetlerinin yüksek olması önemli sorunlardır. Rüzgâr türbinlerinin elektrik üretim verimi bazı kayıplardan dolay1 \%59'dan daha düşük seviyelerdedir.

Rüzgâr türbininden üretilen elektriğin hesabında rüzgâr hızı ve pervane çap1 oldukça önemlidir. Türkiye'nin en iyi rüzgâr rezervi kıyı bölgeleri, yüksek tepeler ve açık alanlarıdır (Elibüyük, Yakut, \& Üçgül B A, 2016). Türkiye RES kurulu gücü 2019 yılında 7,615 MW mertebesinde iken 2020 y1lı sonunda rüzgâr enerjisi kurulu gücü 9,305 MW çıkarak elektrik tüketiminin yaklaşık \%10 tek başına karşılamıştır. (Türeb, 2021). Türkiye 50 metre yükseklikteki rüzgâr potansiyeli atlası şekil 9'de verilmiştir (MGM, 2021) 

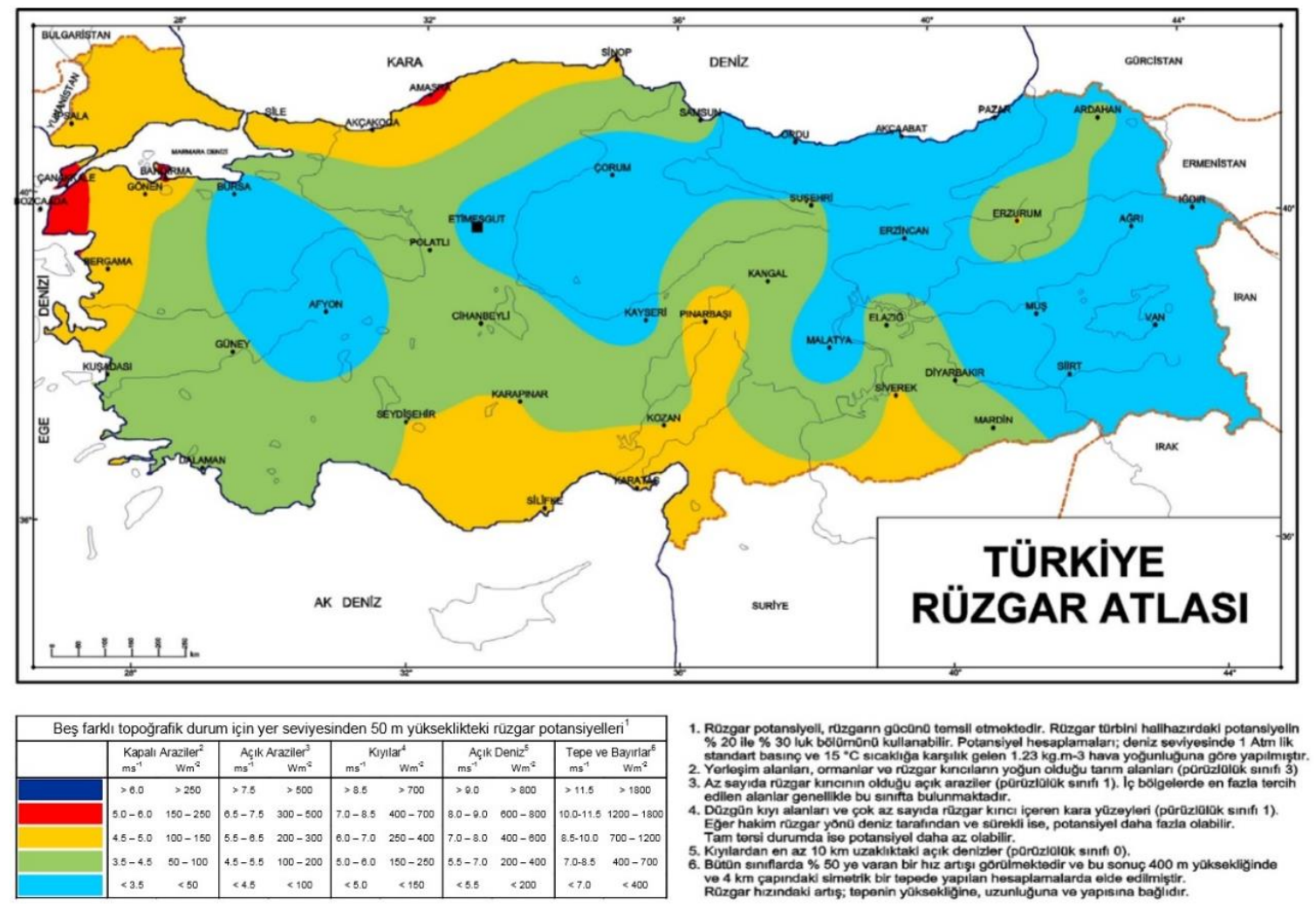

Şekil 9 Türkiye 50 metre yükseklikteki rüzgâr potansiyeli

Türkiye'nin karasal rüzgâr enerji potansiyeli bürüt 400 milyar $\mathrm{kWh} / \mathrm{yl}$, teknik olarak 120 milyar $\mathrm{kWh} / \mathrm{y} 1$ olarak öngörülmektedir (Çelikdemir \& Özdemir, 2020).Rüzgâr türbini tam kapasiteye $15 \mathrm{~m} / \mathrm{s}$ hızla esen rüzgârda ulaşır. $20 \mathrm{~m} / \mathrm{s}$ hızda pervaneler otomatik olarak güvenlik nedeniyle durur. Rüzgâr enerjinsin gücünü hesaplamak için denklem 6 kullanılır (Ekolojist, 2018).

$\mathrm{P}($ Watt $)=1 / 2 \times \rho\left(\frac{\mathrm{kg}}{m^{3}}\right) \times V^{3}\left(\frac{\mathrm{m}}{s}\right) \times C p \times A\left(m^{2}\right)$ 8

$A=\pi r^{2}$

Burada $P$ rüzgâr türbininin üreteceği gücü, $\rho$ hava yoğunluğunu, $\mathrm{V}$ ortalama rüzgâr hızını, $C p$ rüzgâr türbinin yüzdelik katsayısını, A rüzgâr türbininin kanatlarının süpürdüğü alanı ifade eder. Türbin kanatlarının süpürdüğü alan rotor çapı ile hesaplanabilir. Hava yoğunluğu atmosferik şartlarda 1,225 $\frac{\mathrm{kg}}{\mathrm{m}^{3}}$ 'tür. Rüzgâr türbinin Betz limitinde $\% 59.26$ verimlilikte olduğu için Cp değeri 0.5926'dir.

Türbin yüksekliğindeki rüzgâr hızı denklem 10 'da gösterilen Hellmann denklemi ile belli hesaplanabilir (Çelikdemir \& Özdemir, 2020).

$\frac{\mathrm{V}}{v_{0}}=\left(\frac{\mathrm{H}}{\mathrm{H}_{0}}\right)^{a}$
Burada $\mathrm{V} H$ yüksekliğinde ki rüzgâr hızı, $v_{0}$ referans yükseklikteki rüzgâr hızı, H rüzgâr hızının hesaplanmak istediği yükseklik, $H_{0}$ referans yükseklik, $a$ sürtünme katsayısını temsil etmektedir. Referans rüzgâr hızı ve referans yükseklik daha önceden bilinen belli yükseklikteki rüzgâr hızıdır. Sürtünme katsayısı bölgeler arası değişmektedir. Bazı bölgelerin rüzgâr sürtünme katsayıları tablo 3 'te verilmiştir (Masters, 2013).

Tablo 3 Bölge karakteristiğine göre rüzgâr sürtünme katsaylsl

\begin{tabular}{|l|c|}
\hline \multicolumn{1}{|c|}{ Arazi karakteristiği } & $\begin{array}{c}\text { Sürtünme } \\
\text { Katsayısı }\end{array}$ \\
\hline Sert zemin göl ve deniz yüzeyi & 0.10 \\
\hline Çimli açı alan & 0.14 \\
\hline Seyrek ağaçlık ve aralıklı bina alanı & $0.22-0.28$ \\
\hline Kırsal orman alanı & 0.25 \\
\hline Sık ağaçlık bölge & $0.28-0.30$ \\
\hline Yüksek binalar ve şehir içi & 0.40 \\
\hline
\end{tabular}

Türkiye'de bölgelerin rüzgâr enerjisi ve hızı değişkenlik göstermektedir. Genel olarak ülkemizdeki bölgelere göre ortalama rüzgâr hızı ve rüzgâr yoğunluğu tablo 4'de gösterilmiştir (Kızıltuğ, 2002). Rüzgâr enerjisinden potansiyel elektrik üretimini hesaplamak için $50 \mathrm{~m}$ yükseklikte rüzgâr hızı ele alınmalıdır. Bunun nedeni Ülkemizdeki rüzgâr türbinlerinin yüksekliği 50m dolaylarındadır (Yıldız, 2021). 
Tablo 4 Bölgelere göre 10 m yükseklikte rüzgâr hızı ve enerjisi yoğunluğu

\begin{tabular}{|c|c|c|}
\hline Bölge İsmi & $\begin{array}{l}\text { Ortalama Rüzgâr } \\
\text { Yoğunluğu }\left(\mathbf{W} / \mathbf{m}^{2}\right)\end{array}$ & Ortalama Rüzgâr Hızı (m/s) \\
\hline Akdeniz & 21.36 & 2.45 \\
\hline İç Anadolu & 20.14 & 2.46 \\
\hline Ege & 23.47 & 2.65 \\
\hline Karadeniz & 21.31 & 2.38 \\
\hline Doğu Anadolu & 13.19 & 2.12 \\
\hline Güney Doğu Anadolu & 29.33 & 2.69 \\
\hline Marmara & 51.91 & 3.29 \\
\hline
\end{tabular}

\section{Araştırma Sonuçları ve Tartışma}

\subsection{Yerli Elektrikli Aracın Elektrik Sarfiyatına Etkisi}

Yerli TOGG elektrikli araçta $200 \mathrm{HP}$ ve $400 \mathrm{HP}$ güçte iki motor seçeneği ve $45 \mathrm{kWh}$ ve $90 \mathrm{kWh}$ batarya seçeneği sunulmaktadır. (TOGG, 2020). Ayrıca yerli araç otonom destek alt yapısına, internet ağına, kişisel navigasyon ve rehbere ve meteoroloji gibi kurumlar ile anlık olarak veri alışverişinde bulunacağ 1 için elektrik motorunun enerji tüketimine ilave enerjiye ihtiyaç vardır. İlave olarak elektrikli aracın klima, radyon iletişim ekranı, elektrikli cam, elektrikli aynalar ve farlar gibi elektrikli aksesuarların ek enerji sarfiyatı vardır. Elektrikli araçta motorun enerji sarfiyatına ilave olarak toplam $3 \mathrm{kWh}$ enerji harcayacağı öngörülmektedir.

Elektrikli araç enerji tüketimi menzil hesaba katılmadan motor gücüne bağlı olarak $100 \mathrm{~kW}$ motor gücü, $\% 80$ motor verimi, \%100 motor yükü ve günlük ortalama 2 saat araç kullanım süresi kabulleri dikkate alınıp denklem 2'ye göre hesaplandığında

$$
E_{T}=100 \mathrm{~kW} \times 0.80 \times 0.85 \times 2 \mathrm{~h} ; \quad E_{T}=136 \mathrm{kWh}
$$

enerji tüketimi meydana gelmektedir. Bir kişinin günlük şehir içi araç kullanımı İstanbul'da ortalama 3 saattir. TOGG yerli elektrikli aracın sahip olduğu $45 \mathrm{kWh}$ ve $90 \mathrm{kWh}$ bataryaların kapasitelerinin \%90 kullanım oranı baz alınmıştır. Yerli elektrikli araçların tam kapasite batarya ile $300 \mathrm{~km}$ ve $500+\mathrm{km}$ menzil seçeneklerinin günlük şehir içi kullanımı için oldukça yeterli olmasından dolayı günlük araç kullanım süresi yerine batarya şarj çevrim sayısı baz alınmıştır. Ayrıca elektrikli aracın klima, elektrikli aynalar, diğer araçlar ile iletişim ve anlık veri paylaşımı gibi aktif güç tüketen aksesuarların $3 \mathrm{kWh}$ ek enerji tüketiminin yanı sıra batarya kullanım ömrünü en uzun seviyede olabilmesi için batarya tam kapasitenin \%80 'nin kullanılmasından dolayı 45 kWh kapasiteli bataryalı araç günde 1 sefer tam kapasite, 90 kWh kapasiteli bataryalı araç 2 günde bir 1 sefer tam kapasite şarj edilme değerleri baz alındığında 1 adet elektrikli aracın günlük enerji tüketimi:

$$
\begin{gathered}
E_{V 1}=B_{G} \cdot \eta_{B} \cdot C_{n}=45 \mathrm{kWh}^{*} 0.8 \times 1, E_{V 1}=36 \mathrm{kWh} \\
E_{V 1}=B_{G} \cdot \eta_{B} \cdot C_{n}=90 \mathrm{kWh}^{*} 0.8 \times 0.5 \quad E_{V 2}=36 \mathrm{kWh}
\end{gathered}
$$

Her ne kadar Türkiye'de iş günümüz tarihi itibari ile elektrikli araç sayısı 1012 adet olsa da birkaç yıl içinde bu sayı on binleri bulacağı öngörülmektedir. Yerli TOGG elektrikli araç 2022 y1lında seri üretim bandından ineceği ve 10 yıl içinde 1 milyon adet üretim yapılacağı planlanmaktadır (TOGG, 2020). Dolayısıyla iç pazar ve dış pazarın etkisiyle ülkemizde yakın gelecek projeksiyonunda sayıları milyonları bulacak elektrikli araçların ülkemizin günlük elektrik tüketimine ilave elektrik sarfiyatı hesaplanmalıdır. Böylelikle günlük şarj ve 100.000 adet araç için enerji tüketimi:

$$
\begin{gathered}
E_{V 1}=E_{V 2}=36 \times 100,000 / 1000 \\
E_{V 1}=E_{V 2}=3600 \mathrm{MWh}
\end{gathered}
$$

olacaktır. Önümüzdeki 20 yıl içinde Türkiye'de kayıtlı elektrikli araç sayısı 1 milyon olacağı öngörüsü hesaba katıldığında ilave EA elektrik tüketimi:

$$
\begin{gathered}
E_{V 1}=E_{V 2}=0.036 \text { MWhx } 1,000,000 / 1000 \\
E_{V 1}=E_{V 2}=36 \mathrm{GWh}
\end{gathered}
$$

EA aracı günde 1 sefer şarj edilmesi durumunda elektrik tüketim miktarı tablo 6'da verilmiştir.

Tablo 6 Elektrikli aracın günlük 1 kez şarj yapılması durumda elektrik sarfiyatı

\begin{tabular}{|c|c|c|}
\hline 1 araç & 100 bin araç & 1 milyon araç \\
\hline $36 \mathrm{kWh}$ & $3600 \mathrm{MWh}$ & $36 \mathrm{GWh}$ \\
\hline
\end{tabular}

Türkiye'nin günlük elektrik tüketimi ortalama 886,616 MWh’tir (Atlas1, 2019; Hakyemez, 2021). Böylelikle Türkiye'de sadece 100.000 adet elektrikli araç olması durumunda günlük elektrik tüketimine ortalama $\% 0.406$ ve oranında yük ilave binecektir. EA sayısı 1 milyon sayısına ulaştığında enerji sarfiyatı yaklaşık olarak ortalama \%4.06 artacaktır.

\subsection{Güneş enerjinsin EA kaynaklı elektrik sarfiyatını karşılama potansiyeli}

Türkiye yolarında görülen ve sayısı kısa vadede milyonları bulacak olan elektrikli araçların tablo 6'de gösterilen ek elektrik tüketimini sağlamak için oldukça önemli oranda ve hızlı olarak elektrik üretim kurulu güç artırılmalıdır. Elektrik üretim 
kapasitesini hızlı şekilde artırmak için hem kurulum maliyeti hem de yılın her döneminde elektrik üretme kapasitesine sahip güneş panelleri tarlaları kullanılmalıdır.

Güneş paneli kullanarak elektrik üretim yapıldığında öncelikle panel, batarya ve invertörden oluşan sistemin toplam verimi hesabını denklem 4 ile yapılır. Hesaplarda güneş paneli gücünü 1000 Watt panel verimliliği \%80, akü verimliliği \%80 ve invertör verimliliği \%90 olarak kabul edilmiştir.

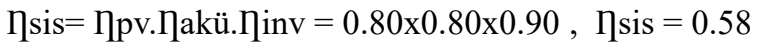

Yerli elektrikli araç sayısı 1 milyon olması durumunda yaklaşık olarak ortalama her iki bataryalı araç için $E_{T 1}=E_{T 2}=$ $36 \mathrm{GWh}$ günlük enerjiye ihtiyacı vardır. $\mathrm{Bu}$ enerjiyi GES kullanarak karşılamak için kaç adet güneş paneline ihtiyaç olduğu denklem 6 ile hesaplanır.

\section{$\mathrm{Ps}_{1}=36$ GWh $x 1000000000 / 1000 W x 7 h$}

$$
\mathrm{Ps}_{1}=\mathrm{Ps}_{2}=5,042,016 \text { adet }
$$

Aktif olarak 1 milyon $45 \mathrm{kWh}$ ve $90 \mathrm{kWh}$ elektrikli aracın günde $1 \mathrm{kez}$ ve 2 günde $1 \mathrm{kez}$ şarj sayılıları ile ihtiyaç duyduğu $36 \mathrm{GWh}$ elektrik enerjisi ihtiyacını sağlamak için güneş enerjisinden faydalandığında 1000 Watt gücünde yaklaşık olarak Ps $=5$ milyon adet panele ihtiyaç vardır. Kullanılan güneş paneli tipine göre enerji üretim kapasitesi değişmektedir. Türkiye'de Kadmium tellerium tip panel ile $100 \mathrm{~m}^{2}$ alanda yaklaşı 12,000 $\mathrm{kWh} / \mathrm{y} 1 \mathrm{l}$ üretim yapılabilirken Monokristalin silikon tip panel ile $100 \mathrm{~m}^{2}$ 26,000 kWh/yıl üretim yapılabilir (GEPA, 2021). Yüz ölçümü göre günülük ilave elektrik üretimi Monokristalin silikon tip güneş panelleri ile sağlandığında Türkiye yüzölçümünün \%6.13 kadarı güneş paneli ile kaplanmalıdır. Güneşlenme süresi Türkiye'nin ortalama güneşlenme süresinden daha uzun olan Güney Doğu Anadolu ve Akdeniz bölgelerinde kurulacak GES'ler ile bu maliyetler \%14.64 ve $\% 12.5$ oranında azaltılabilir.

\subsection{Rüzgâr enerjinsin EA kaynaklı elektrik sarfiyatını karşılama potansiyeli}

Elektrikli aracın günlük ek elektrik sarfiyatının karşılanmasında güneş enerjisinin yanı sıra rüzgâr enerjisinde oldukça aktif olarak kullanılabilir. Türkiye'nin Rüzgâr enerji potansiyelinin $400 \mathrm{GWh} / \mathrm{yll}$ seviyesindedir. Bu potansiyel mevcut

\section{Sonuç ve Öneriler}

Bu çalışmada, elektrikli araçların sayıları önümüzdeki 10 yıl içinde 100 binleri bulması beklendiğinden dolayı yerli elektrikli araç özellikleri kullanılarak ülkemizin elektrik sarfiyatına ek elektrik yükü ve bu ek elektrik sarfiyatının temiz enerji kapsamında güneş enerji ve rüzgâr enerjisi ile sağlanabilirliği araştırılmıştır.

- Yerli elektrikli araçlar sıfır emisyon ürettiği için taşıt kaynaklı zararlı ve sera etkili emisyonları önemli oranlarda azaltır.

- Yerli TOGG veya farklı marka elektrikli araçların 45 kWh gücünde ki bataryaların güde $1 \mathrm{kez}, 90 \mathrm{kWh}$ gücündeki bataryaların 2 günde $1 \mathrm{kez}$ şarj edilmesi durumunda ve toplam araç sayısı 1 milyon âdete ulaşması halinde Türkiye'nin günlük elektrik sarfiyatı 36 GWh ilave ile \%4.06 artacaktır.
RES modüllerinden daha verimli türbin sistemleri ile artırılabilir. Tepe ve bayırlarda $50 \mathrm{~m}$ yükseklikteki ortalama rüzgâr hızı ve rüzgâr enerjisi yoğunluğu kullanarak yaklaşım yöntemi ile rüzgâr enerjisinden elektrik gücü etmek için denklem 9 kullanılmıştır. Ortalama rüzgâr hızı $9.14 \mathrm{~m} / \mathrm{s}$, rüzgâr yoğunluğu enerjisi 1200 $\mathrm{w} / \mathrm{m}^{2}$, hava yoğunluğu $1.23 \mathrm{~kg} / \mathrm{m}^{3}$ olarak alınmıştır. Türbin rotor yarı çap1 (r) 30m ve türbin kule uzunluğu $100 \mathrm{~m}$ olarak kabul edilmiştir. Türbin yüksekliği olan 100 m yükseklikte rüzgâr hızı denklem 10' göre hesaplanmıştır.

$$
\begin{gathered}
\frac{\mathrm{V}}{v_{0}}=\left(\frac{\mathrm{H}}{H_{0}}\right)^{a}, \frac{\mathrm{v}}{9.54}=\left(\frac{70}{50}\right)^{0.14}, \mathrm{v}=12.79 \mathrm{~m} / \mathrm{s} \\
A=\pi r^{2}=\pi 30^{2}, \mathrm{~A}=2,827.43 \mathrm{~m}^{2} \\
\mathrm{P}(\text { Watt })=\frac{1}{2} \times \rho\left(\frac{\mathrm{kg}}{\mathrm{m}^{3}}\right) x V^{3}\left(\frac{\mathrm{m}}{\mathrm{s}}\right) \times C p x A\left(\mathrm{~m}^{2}\right), \\
\mathrm{P}=\frac{1}{2} \times 1.23 \times 12.79^{3} \times 0.5926 \times 2,827.43 \\
\mathrm{P}=2,158,993.42 \mathrm{~W}=2158.993 \mathrm{~kW}, \mathrm{P}=2.159 \mathrm{MW}
\end{gathered}
$$

Rüzgâr türbini bir yıl boyunca sürekli çalınması durumunda $1 \mathrm{MW}$ gücündeki türbin tam verim ile $8,760 \mathrm{MWh}$ elektrik üretimi yapabilir (Karık, Sözen, \& İskender, 2015). Fakat jeneratör verimi ve sistem kapasite faktörü ile bu verim yaklaşık \%50 azalmaktadır. Rüzgâr türbini enerji potansiyeli yıllık 18,912.84 MWh olarak hesaplanır. Fakat toplam RES verimi \%50 olarak alındığında üretilen yıllık güç $\left(\mathrm{P}_{\ddot{U}}\right)$ hesabı 9,456.42 MWh olarak hesaplanır.

$$
\mathrm{P}_{\mathrm{U}}=18,912.84 \times 0.5=9,456.42 \mathrm{MWh}
$$

Rüzgâr enerjisinden elektrik üretim potansiyelini artırmak ve elektrikli aracın günlük olarak ek elektrik sarfiyatını karşılamak için bu güçte yaklaş1k olarak 1390 adet rüzgâr türbine ihtiyaç vardir.

$$
\text { Ts }=36000 * 365 / 9456.42 \cong 1390
$$

Rüzgâr hızı ortalaması aylara ve iklime göre değişmesinden dolayı gerekli türbin sayısı daha da artacaktır. Rüzgâr türbin sayısı ve RES verimi artırılırsa karşılama potansiyeli artırılabilir.

- Türkiye'nin elektrik kurulu gücü oldukça yetersiz olduğu için elektrikli araçların ilave elektrik sarfiyatı dışarıya bağımlılığı artırmayacak rüzgâr enerjisi ve güneş enerjisi gibi yenilenebilir enerji kaynakları ile karşılanabilir. Potansiyel güneş enerjisi elektrik üretimi ile ilave elektrik sarfiyatının tamamını karşılamak için yaklaşık $1000 \mathrm{~kW}$ gücünde 5 milyon adet güneş paneline veya potansiyel rüzgâr enerjisi ile karşılamak için 2.159 MW gücünde yaklaşı 1390 adet rüzgâr türbinine ihtiyaç vardir.

- GES ve RES ayrı ayrı kurulum maliyetleri ve ani günlük iklim durumunun değişebilmesi nedeniyle güneş ve rüzgâr hibrit sistemleri şeklinde kurulmalıdır. Elektrikli araç şarj istasyonlarının yaygınlaşması ve şarj istasyonu problemine hızlı çözüm olabilmesi için mevcut konvansiyonel akaryakıt istasyonlarına çatı tip güneş ve rüzgâr sistemleri kurulması teşvik edilmelidir. Türkiye'de Mevcut yakıt istasyon sayısı yaklaşık 15,000 
civarında olmasından dolayı her istasyonda rüzgâr ve güneş sistemlerinin kurulması durumunda uzun vadede elektrik şarj istasyon sorunu çözülebilir. Ayrıca şekil 7'deki gibi açık otoparkların üzerlerine çatı tipi güneş panelleri ile elektrik şarj istasyonu kurulması teşvik ile yönlendirilebilir.

- Elektrikli araç şarj istasyonu sorunu elektriğe duyulan ihtiyacın azaltılması ile giderilebileceğinden dolayı bu soruna önemli çözümlerden biride PEM tarzı yakıt hücreleri ile elektrikli araçların desteklenmesi ve mevcut yakıt istasyonlarında hidrojen dolum istasyonları ile azaltılabilir.

\section{Terimler}

$\begin{array}{ll}\text { BEV } & \text { Bataryalı elektrikli araç } \\ \text { CNG } & \text { Sıkıştırılmış doğal gaz } \\ \text { CSP } & \text { Odaklanmış Güneş Enerjisi } \\ \text { DC } & \text { Doğru akım } \\ \text { EA } & \text { Elektrikli araç } \\ \text { EEA } & \text { Avrupa ekonomik Alanı } \\ \text { EGR } & \text { Egzoz gazı devirdaimi } \\ \text { ETKB } & \text { Enerji tabi kaynaklar bakanlığı } \\ \text { FCEV } & \text { Yakıt hücreli elektrikli araç } \\ \text { GEP } & \text { Güneş enerjisi potansiyeli } \\ \text { GEPA } & \text { Güneş enerjisi potansiyel atlası } \\ \text { GES } & \text { Güneş enerji sistemleri } \\ \text { GHG } & \text { Sera gazları } \\ \text { HEV } & \text { Hibrit elektrikli araç } \\ \text { LNG } & \text { Doğal gaz } \\ \text { LPG } & \text { Sıvılaştırılmış petrol gazı } \\ \text { PEM } & \text { Proton elektron membran } \\ \text { PM } & \text { Partikül madde } \\ \text { PV } & \text { Fotovoltaik panel } \\ \text { RES } & \text { Rüzgâr enerji sistemleri } \\ \text { TEİAŞ } & \text { Türkiye elektrik iletim A.Ş. } \\ \text { TOGG } & \text { Türkiye otomotiv girişim grubu } \\ \text { TÜ̇K } & \text { Türkiye istatistik kurumu } \\ \text { TÜREB } & \text { Türkiye rüzgâr enerjisi birliği } \\ \end{array}$

\section{Birimler}

$\begin{array}{ll}\text { GWh } & \text { Gigawatt saat } \\ \text { kg } & \text { Kilogram } \\ \text { kWh } & \text { Kilowatt saat } \\ \text { MWh } & \text { Megawatt saat } \\ \text { m } & \text { Metre } \\ \text { s } & \text { Saniye } \\ \text { Watt } & \text { Watt }\end{array}$

\section{Kaynakça}

Adler, K. (2021). IHS Markit forecasts global EV sales to rise by $70 \%$ in 2021 . Retrieved March 10, 2021, from https://ihsmarkit.com/research-analysis/ihs-markit-forecastsglobal-ev-sales-to-rise-by-70-percent.html

Agency EA. (2019). 2019 Experiential Marketing Trend Report. Retrieved from https://agencyea.com/insights/2019experiential-marketing-trend-report/

Alkan, S., Öztürk, A., Zavrak, S., Tosun, S., \& Avc1, E. (2014). Bir Evin Elektrik Enerjisi İhtiyacını Karşılayacak Fotovoltaik Sistemin Kurulumu. In Elektronik - Bilgisayar ve Biyomedikal Mühendisliği Sempozyumu, 27 - 29 Kasım (pp.
78-82). Bursa. $\quad$ Retrieved from https://www.emo.org.tr/ekler/12f562f9f252bd3_ek.pdf

Allen, M., Babiker, M., Chen, Y., Taylor, M., Tschakert Australia, P., Waisman, H., ... Waterfield, T. (2018). Summary for Policymakers - Global Warming of $1.5^{\circ} \mathrm{C}$. Aromar Revi. Retrieved from https://www.ipcc.ch/site/assets/uploads/sites/2/2019/05/SR1 5_SPM_version_report_LR.pdf

Atakul, Ş., Kalender, M. A., Gezici, M., \& Konuralp Eliçin, A. (2015). Güneş Tarlası Kurulumu. Tarım Makinaları Bilim Dergisi (Journal of Agricultural Machinery Science), 2015(1), 55-60. Retrieved from https://dergipark.org.tr/tr/download/article-file/445009

Atlası, E. (2019). Türkiye Elektrik Tüketimi. Retrieved March 11, 2021, from https://www.enerjiatlasi.com/elektrik-tuketimi/

Bae, C., \& Kim, J. (2017). Alternative fuels for internal combustion engines. Proceedings of the Combustion Institute, 36(3), 3389-3413. https://doi.org/10.1016/j.proci.2016.09.009

Bayrak, Y. (2020). Türkiye’nin Enerji Görünümü , Yakın Dönem (2020-2025) Elektrik Üretim-Tüketim Projeksiyonuna Yönelik Bir Çözümleme. Retrieved from https://www.mmo.org.tr/sites/default/files/TEG-20204.2_Yakın Dönem Projeksiyonu_Yusuf Bayrak.pdf

Behrentz, E., Ling, R., Rieger, P., \& Winer, A. M. (2004). Measurements of nitrous oxide emissions from light-duty motor vehicles: A pilot study. Atmospheric Environment, 38(26), 4291-4303. https://doi.org/10.1016/j.atmosenv.2004.04.027

BMW. (2021). Elektrikli otomobil türleri. Retrieved March 10, 2021, from https://www.bmw.com.tr/tr/topics/fascinationbmw/bmw-i-ve-e-mobilite/elektrikli-otomobil-turleri.html

Brijesh, P., \& Sreedhara, S. (2013). Exhaust emissions and its control methods in compression ignition engines: A review. International Journal of Automotive Technology, 14(2), 195206. https://doi.org/10.1007/s12239-013-0022-2

Çelikdemir, S., \& Özdemir, M. T. (2020). Adilcevaz Bölgesinde Rüzgâr Enerji Potansiyelinin İncelenmesi. BEÜ Fen Bilimleri Dergisi , 9(1), 204-214.

Cellek, M. S. (2020). Kaya Gazlarının Yanma Karakteristikleri ve İs oluşumu. European Journal of Science and Technology, (22), 49-59. https://doi.org/10.31590/ejosat.839848

Çiçek, A., \& Erdinç, O. (2019). PV-Batarya Hibrit Sistemi İçeren Elektrikli Araç Otoparkının Şarj Yönetimi. European Journal of Science and Technology, (15), 466-474. https://doi.org/10.31590/ejosat.527350

Civles, M., \& İrem, Z. (2018). Elektrikli araçlar. Retrieved from https://www.dunyaenerji.org.tr/wpcontent/uploads/2018/09/YET3-1.pdf

Çobanoğlu, A., Demirkıran, G., \& Güneş, M. (2021). İzmir İlinde Elektrikli Kara Araçları için Güneş Enerjisi Destekli Bir Şarj İstasyonunun Tasarlanmas1. European Journal of Science and Technology, (21), 635-648. https://doi.org/10.31590/ejosat.777874

De Cauwer, C., Van Mierlo, J., \& Coosemans, T. (2015). Energy consumption prediction for electric vehicles based on realworld data. Energies, 8(8), 8573-8593. https://doi.org/10.3390/en8088573

Deloitte. (2019). New market. New entrants. New challenges. Battery Electric Vehicles.

Doğanay, H., Özdemir, Ü., \& Şahin, F. İ. (2020). Genel Beşerî Ve Ekonomik Coğrafya (11th ed.). Pegem Akademi. https://doi.org/10.14527/9786053641193 
EEA. (2019). Trends and projections in Europe 2019 - Tracking progress towards Europes climate and energy targets. https://doi.org/10.2800/51114

Ekolojist, net. (2018). Rüzgar Enerjisi Güç Hesab1 . Retrieved March 11, 2021, from https://ekolojist.net/ruzgar-enerjisiguc-hesabi

Elibüyük, U., Yakut, A. K., \& Üçgül B A, İ. (2016). Süleyman Demirel Üniversitesi Rüzgâr Enerjisi Santrali Projesi. Süleyman Demirel Üniversitesi Yekarum E-Dergi, 3(2), 2232.

Enerji Atlası. (2021). Türkiye Güneş Enerjisi Potansiyeli Haritası. Retrieved March 11, 2021, from https://www.enerjiatlasi.com/gunes-enerjisi-haritasi/turkiye

Eriksson, E. L. V., \& Gray, E. M. A. (2017). Optimization and integration of hybrid renewable energy hydrogen fuel cell energy systems - A critical review. Applied Energy, 202, 348364. https://doi.org/10.1016/j.apenergy.2017.03.132

ETKB. (2020). Güneş. Retrieved March 10, 2021, from https:/enerji.gov.tr/bilgi-merkezi-enerji-gunes

GEP. (2021). Güneş Paneli Fiyatları. Retrieved March 11, 2021, from http://gunesenerjisipanelleri.net/gunes-paneli-fiyatlari/

GEPA. (n.d.). Türkiye PV tipi alan-Üretilebilecek enerji $(\mathrm{kWh} / \mathrm{y} 1 \mathrm{l})$. Retrieved March 15, 2021, from https://gepa.enerji.gov.tr/MyCalculator/

Gezegen, S. (2021). Rüzgar Türbini Enerji Hesab1 - Enerjim Güneşten. Retrieved March 11, 2021, from https://www.enerjimgunesten.com/ruzgar-turbini-enerjihesabi.html

Ghosh, A. (2020). Possibilities and Challenges for the Inclusion of the Electric Vehicle (EV) to Reduce the Carbon Footprint in the Transport Sector: A Review. Energies, 13(10), 2602. https://doi.org/10.3390/en13102602

Gürbüz, H. (2020). Analysis of the effects of multiple injection strategies with hydrogen on engine performance and emissions in diesel engine. International Journal of Hydrogen Energy, 45(51), 27969-27978. https://doi.org/10.1016/j.ijhydene.2020.07.012

Gürbüz, H., \& Sandalc1, T. (2019). Investigation of Effects of Fumigation on Performance and Emission in Dual Fuel Engines Injection-Controlled With Electronic Card. International Journal of Engineering Research and Advanced Technology, 5(3), 24-31. https://doi.org/10.31695/ijerat.2019.3400

Hacıbebekoğlu, A., Maden, Ö.; \& Demirliçakmak, E. (2013). Güneş Panelleri Imalatı Yatırım Fizibilitesi. Retrieved from https://www.oran.org.tr/materyaller/Editor/document/Planla maBirimi/Dokmerkezi/Fizibilite_Raporlari/Güneş Panelleri İmalatı Yatırım Fizibilitesi.pdf

Hakyemez, C. (2021). Ayllk Enerji Bülteni Ocak 2021. Retrieved from https://www.tskb.com.tr/i/assets/document/pdf/enerjibulteni-ocak-2021.pdf

Huang, Y., Surawski, N. C., Organ, B., Zhou, J. L., Tang, O. H. H., \& Chan, E. F. C. (2019). Fuel consumption and emissions performance under real driving: Comparison between hybrid and conventional vehicles. Science of the Total Environment, 659 , $275-282$. https://doi.org/10.1016/j.scitotenv.2018.12.349

Hyodo, T., Watanabe, D., \& Wu, M. (2013). Estimation of energy consumption equation for Electric Vehicle and its implementation of driving behaviour . Tokyo. Retrieved from http://www.wctrs-society.com/wpcontent/uploads/abstracts/rio/selected/1356.pdf

IEA. (2019). Global EV Outlook 2019. Retrieved from https://www.iea.org/reports/global-ev-outlook-2019

Karık, F., Sözen, A., \& İskender, Ü. (2015). Türkiye'de Rüzgar Enerjisinde Mevcut Durum. Gazi Mühendislik Bilimleri Dergisi, 1(2), 219-234. Retrieved from https://dergipark.org.tr/tr/download/article-file/302956

Keskin, A., \& Emiroğlu, O. A. (2016). Catalytic Reduction Techniques For Post-Combustion Diesel Exhaust Emissions. Fuels And Combustion in Engineering Journal, (1), 16-21. Retrieved from https://dergipark.org.tr/tr/pub/fce/313115

Kizlltuğ, M. (2002). Wind Energy. Istanbul Technical University.

Köroğlu, T., Teke, A., Bayındır, K. Ç., \& Tümay, M. (2010). Güneş Paneli Sistemlerinin Tasarımı. Elektrik Mühendisliği Dergisi, (439), 98-104. Retrieved from https://www.emo.org.tr/ekler/8e692a34a5e564e_ek.pdf?derg $\mathrm{i}=610$

López, I., Ibarra, E., Matallana, A., Andreu, J., \& Kortabarria, I. (2019). Next generation electric drives for HEV/EV propulsion systems: Technology, trends and challenges. Renewable and Sustainable Energy Reviews, 114, 109336. https://doi.org/10.1016/j.rser.2019.109336

Luo, Y. (2010). Wind Turbine Site Selection Over Abandoned Mined Land. In NAAMLP 32nd Annual Conference, Sept. 1922, 2010, Scranton, $P A$ (pp. 2-16).

Manoharan, Y., Hosseini, S. E., Butler, B., Alzhahrani, H., Senior, B. T. F., Ashuri, T., \& Krohn, J. (2019). Hydrogen Fuel Cell Vehicles; Current Status and Future Prospect. Applied Sciences, 9(11), 2296. https://doi.org/10.3390/app9112296

Martínez-Lao, J., Montoya, F. G., Montoya, M. G., \& ManzanoAgugliaro, F. (2017). Electric vehicles in Spain: An overview of charging systems. Renewable and Sustainable Energy Reviews, 77, 970-983. https://doi.org/10.1016/j.rser.2016.11.239

Martins, J., \& Brito, F. P. (2020). Alternative fuels for internal combustion engines. Energies, 13(15), 2-33. https://doi.org/10.3390/en13164086

Masters, G. M. (2013). Renewable and Efficient Electric Power Systems, (2nd Edition). Wiley-IEEE Press. Retrieved from https://www.wiley.com/en-

us/Renewable+and+Efficient + Electric + Power + Systems $\% 2 \mathrm{C}$ +2 nd+Edition-p-9781118633502

MGM, M. G. M. (2021). Türkiye Rüzgar Atlası. Retrieved March 11, 2021, from https://mgm.gov.tr/genel/ruzgar-atlasi.aspx

Mruzek, M., Gajdáč, I., Kučera, L., \& Barta, D. (2016). Analysis of Parameters Influencing Electric Vehicle Range. Procedia Engineering, 134, $165-174$ https://doi.org/10.1016/j.proeng.2016.01.056

Oral, M. (2020). Türkiye'nin Güneş Enerjisi Potansiyeli ve PV Uygulamalarının Yerel Ölçekte Değerlendirilmesi: Karabük İli Örneği. Lnternational Journal of Geography and Geography Education, 42(42), 482-503. https://doi.org/10.32003/igge.743513

Özdoğan, F. S., \& Bitlisli, F. (2019). Güneş Enerjisi ile Elektrik Üreten İşletmelerin Muhasebe Uygulamalarının TDHP ve TMS/TFRS Çerçevesinde Karşılaştırılması . Balıkesir University The Journal of Social Sciences Institute, 22(42), 255-279. https://doi.org/10.31795/baunsobed.657853

Özgür, E. (2020). Türkiye'nin Enerji Görünümü. Retrieved from https:/www.mmo.org.tr/sites/default/files/TEG-202012_Türkiye\%27de Güneş Enerjisi_Evren Özgür.pdf

Ozsezen, A. N., \& Canakci, M. (2011). Performance and combustion characteristics of alcohol-gasoline blends at wide-open throttle. Energy, 36(5), 2747-2752. https://doi.org/10.1016/J.ENERGY.2011.02.014 
Pedrozo, V. B., May, I., Dalla Nora, M., Cairns, A., \& Zhao, H. (2016). Experimental analysis of ethanol dual-fuel combustion in a heavy-duty diesel engine: An optimisation at low load. Applied Energy, 165, 166-182. https://doi.org/10.1016/j.apenergy.2015.12.052

Rezaei, A., Burl, J. B., Solouk, A., Zhou, B., Rezaei, M., \& Shahbakhti, M. (2017). Catch energy saving opportunity (CESO), an instantaneous optimal energy management strategy for series hybrid electric vehicles. Applied Energy, 208 , 655-665. https://doi.org/10.1016/j.apenergy.2017.09.089

Sarıkaya, S. (2012). Güneş Enerjisi Sektör Raporu. Retrieved from

https://www.kalkinmakutuphanesi.gov.tr/assets/upload/dosy alar/g-c3-bcne-c5-9f-20enerjisi-20sekt-c3-b6rel-20analiz20raporu.pdf

Saygın, D., Bülent, O., Teimourzadeh, S., Hildermeier, J., Koç, M., \& Kolokathis, C. (2019). Türkiye ulaştırma sektörünün dönüşümü: Elektrikli araçların Türkiye dağıtım şebekesine etkileri. Retrieved from https://www.shura.org.tr/wpcontent/uploads/2019/12/Turkiye-ulastirma-sektorunundonusumu-Elektrikli-aracların-Turkiye-dagitim-sebekesineetkileri-.pdf

Sayın, A. A., \& Yüksel, İ. (2011). Elektrikli Renault Fluence Arac1,Lityum İyon Bataryasının Modellenmesi ve Batarya Yönetimi. Mühendis ve Makina, 52(615), 75-82. Retrieved from

http://www1.mmo.org.tr/resimler/dosya_ekler/49c18c0be0e 96e2_ek.pdf?dergi $=1129$

Sun, C., Sun, F., \& He, H. (2017). Investigating adaptive-ECMS with velocity forecast ability for hybrid electric vehicles. Applied Energy, 185, 1644-1653. https://doi.org/10.1016/j.apenergy.2016.02.026

Sun, Z., Wen, Z., Zhao, X., Yang, Y., \& Li, S. (2020). Real-World Driving Cycles Adaptability of Electric Vehicles. World Electric Vehicle Journal, 11(1), 19. https://doi.org/10.3390/wevj11010019

TEİAŞ. (2021). 2020 y1lı elektrik-uretim-tuketim-raporu. Retrieved March 10, 2021, from https://www.teias.gov.tr/trTR/aylik-elektrik-uretim-tuketim-raporlari

Teter, J., Tattini, J., \& Petropoulos, A. (2020). Tracking Transport 2020 - Analysis - IEA. Retrieved from https://www.iea.org/reports/tracking-transport-

2020?utm_content=buffer5a8e1\&utm_medium =social\&utm source $=$ twitter.com\&utm_campaign $=\overline{\text { buffer\# }}$

TOGG. (2020). TOGG. Retrieved March 30, 2020, from https://www.togg.com.tr/content/otomobil

Traub, L. W. (2011). Range and endurance estimates for batterypowered aircraft. Journal of Aircraft, 48(2), 703-707. https://doi.org/10.2514/1.C031027

TUIKK. (2020). Motorlu Kara Taşıtları, Aralık 2020. Retrieved March 10, 2021, from https://data.tuik.gov.tr/Bulten/Index?p=Road-MotorVehicles-December-2020-37410

Türeb, T. R. E. B. (2021). Türkiye Rüzgar Enerjisi İstatistik Raporu 2020. Retrieved from https://tureb.com.tr//anasayfa

Wang, J., Besselink, I., \& Nijmeijer, H. (2015). Electric vehicle energy consumption modelling and prediction based on road information. World Electric Vehicle Journal, 7(3), 447-458. https://doi.org/10.3390/wevj7030447

Williams, M., \& Minjares, R. (2016). A technical summary of Euro $6 / V I$ vehicle emission standards. Retrieved from https://theicct.org/sites/default/files/publications/ICCT_Euro
6-VI_briefing june2016.pdf

Yıldız, S. S. (2021). Balıkesir İli Rüzgâr Hızı Haritalarının Hazırlanması ve Rüzgâr Enerjisi Potansiyeli Açısından İncelenmesi. Geomatik, 6(3), 198-206. https://doi.org/10.29128/geomatik.737567 